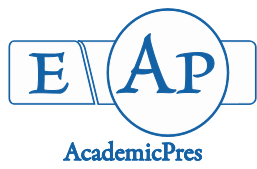

\title{
Responses of Grain Maize to Plant Density at Different Irrigation Regimes
}

\author{
Sara SAMADVAND ${ }^{1}$, Mohammad MAJIDI ${ }^{2 *}$, Gholamreza HEIDARI ${ }^{3}$, \\ Yahya EMAM ${ }^{2}$ \\ ${ }^{1}$ Uromia University, Department of Agronomy and Plant Breeding, Uromia, Iran; \\ ${ }^{2}$ Shiraz University, Department of Agronomy and Plant Breeding, Shiraz, Iran \\ ${ }^{3}$ University of Kurdistan, Department of Agronomy and Plant Breeding, Sanandaj, \\ Iran; mohammadmajidy2012@yahoo.com (*corresponding author)
}

\begin{abstract}
In order to examine the effects of different plant densities, plant patterns and irrigation regimes on yield, yield components and harvest index of grain maize, a field experiment was conducted at Miyandoab Agricultural Research Station, Iran. A strip split plot experiment was conducted based on randomized complete block design with three replications. The results showed that the effect of plant density was significant on kernel yield, harvest index, 1,000 kernel weight. The highest kernel yield was obtained from 90,000 plants ha ${ }^{-1}$ density. Maximum grain yield $\left(18.530 \mathrm{t} \mathrm{ha}^{-1}\right)$ was obtained from furrow irrigation. However, there was no significant difference between moisture levels of $100 \%$ and $120 \%$ of field capacity. The lowest kernel yield was obtained at $80 \%$ field capacity. This study also showed that mean kernel weight and the number of kernels per row were the most determinant factors in grain yield formation. The highest and the lowest harvest indices were obtained at $120 \%$ and $80 \%$ treatments of field capacity treatment, respectively.
\end{abstract}

Keywords: density, harvest index, tape drip irrigation, yield

\section{Introduction}

Water is an important resource for human society and protection of this natural resource efficiently has become one of the main challenges of the century. According to Iran's geographic information, the country is located in a semi-arid region on the Earth. Therefore, it can easily be claimed that the limitation of water resources is one of the major factors in the agricultural development of Iran (Samian et al., 2015). Water availability is one of the most important factors in governing crop production around the world. More than $90 \%$ of the extracted water has been allocated to agricultural section (Baghani and Alizadeh, 2000).

One of the main under-development factors for maize cultivation in Iran is the low efficiency of the crop with conventional irrigation methods (Afshar et al., 2007). Drip irrigation is defined as an irrigation practice where water is dispensed one drop at a time at the desired location. This technology was available for many years and has been recently promoted for applications in different areas (Darusman et al., 1997). Tape drip irrigation system offers steady water drops over time instead of the traditional stream produced by a hose or sprinkler. Drip irrigation offers many benefits and the result of these advantages is creating rapid growth and earlier harvest, crops with high quality at higher yields, as well as cost saving associated with greatly reduced water usage. Surface irrigation is among the widest spread irrigation method. It is normally used when conditions are favourable: existing mild and regular slopes, soil type with medium to low infiltration value and sufficient supply of surface or groundwater. In the case of steep or irregular slopes, soils with a very high infiltration value or scarcity of water, drip irrigation may be more appropriate (Kohi et al., 2005).

Maize (Zea mays L.) management of row spacing and crowed has been used to increase maize yield (Seidehvand, 2000). Widdicombe and Thelen (2002) reported that yield will increases up to $10 \%$ with decreasing row spacing. Murphy et al. (1996) showed that maize planted at rows with $50 \mathrm{~cm}$ intervals will intercept about $8 \%$ more PAR with emergence of silk than crops cultivated at normal rows, decreasing biomass of late emergence. In an experiment, Dahmardeh (2001) showed that maize growth at high density of 100,000 plants per hectare could result in maximum grain yield of maize; therefore, productivity of maize crop will increase. Plant height and yield increases up to the planting density of 71,900 over per hectare in maize, but further increase in plant density has no significant effect on the plant height and biomass yield (Turgut, 2000). 
Plant density in maize affects plant structure, changing growth and developmental patterns, assimilate production and partition (Casal et al., 1985).

The aim of the present study was to investigate the effects of different maize density on yield, yield components and harvest index of maize under different moisture regimes.

\section{Materials and Methods}

In order to examine the effect of different irrigation regimes, plant density and plant pattern on yield, yield components and harvest index of maize, an experiment was conducted at the Miandoab Agricultural Research Station south west of Iran. Soil type was silty-loam (Table 1). Longitude was 46 and 90 degree and latitude was 36 and 58 degree. A Strip Split Plot experiment was conducted based on randomized complete block design with three replications. Irrigation treatments were placed in vertical plots and planting array of different densities was placed in horizontal plots in the form of split plots. The vertical plots comprised four irrigation treatments, including: three levels $(80 \%, 100 \%$ and $120 \%)$ of water requirement by use of drip tape irrigation and $100 \%$ of water requirement in furrow irrigation; the horizontal factor was planting array in the form of single-row and two-rows planting, while the (secondary) sub-factor was comprised of three different densities: 75, 90 and 105 thousand plants per hectare. Each experimental plot had $12 \times 6 \mathrm{~m}$.

Urea was applied at $250 \mathrm{~kg} / \mathrm{ha}$ and phosphorus was added with $200 \mathrm{~kg} / \mathrm{ha}$ as phosphates triple. To impose the irrigation levels, both evapotranspiration pan and crop coefficients methods were used. Then, the water requirement value for each field capacity was calculated by considering $90 \%$ efficiency application. Irrigation levels composed of 80,100 and $120 \%$ field capacity applied by a meter to each plot.

In the final harvest, ear length, number of kernel per row and 1,000 kernal weights were measured.

Collected data were subjected to analysis of variance using MSTATC software. Means were compared by using Duncan multiple range tests at $5 \%$ level.

Table 1. Site characteristics and soil chemical and physical properties

\begin{tabular}{cc}
\hline $\begin{array}{c}\text { Chemical and physical } \\
\text { properties }\end{array}$ & $\begin{array}{c}\text { Depth } \\
(\mathrm{cm})\end{array}$ \\
\hline EC (mmoh/cm) & 0.91 \\
pH & 7.6 \\
Clay $(\%)$ & 25 \\
\hline Silt $(\%)$ & 51 \\
Sand $(\%)$ & 24 \\
\hline Soil texture & Loam - silt \\
\hline Organic carbon $(\%)$ & 1.44 \\
\hline P (ppm) & 37.26 \\
K(ppm) & 891 \\
Fe (ppm) & 9.26 \\
Mn (ppm) & 7.58 \\
Zn (ppm) & $0 / 86$ \\
Cu (ppm) & 1.64 \\
\hline
\end{tabular}

\section{Results and Discussion}

\section{Kernel performance}

Effect of different irrigation systems was significant on harvest index, ear height, length of ear, number of kernel in row, 1,000 kernel weight and grain yield. Also, effect of plant density was significant on harvest index, ear height, plant height, length of ear, number of kernel in row, 1,000 kernel weight and grain yield. Plant pattern had no significant effect on the above mentioned traits. None of the interactions between the experimental factors were statistically significant for studied variables (Table 2).

By a comparison of the related yield affected by different irrigation systems, it was observed that the highest yield value was related to furrow irrigation, with 18.530 tons over per hectare, which was arranged in a statistical group with $100 \%$, and $120 \%$ treatment of water requirements. The lowest value for kernel yield was observed in $80 \%$ treatment of water requirements (14.948 tons per hectare) (Table 3). The analysis of mean comparisons indicated that ear maize yield tended to decrease with decreasing the irrigation level. The results agree with the findings of Howell and colleagues (Howell et al., 1984), too. They suggested that this effect may be because of creating disruption in physiological activities of the plant. Lamm et al. (1994) found similar results. They also found that lower irrigation can lead to a decrease of the ear yield.

According to high efficiency of linear and drip irrigation systems in consuming less water, the results show that the drip irrigation can supply all plants' requirements, while it can cause some stress in $80 \%$ treatment of water requirement due to lack of supplying enough water for plants. Ahmad and Khalili (2009) stated that plant yield value tended to increase with increasing irrigation levels through drip-linear irrigation.

Based on an analysis of comparing density effect means of kernel yield using Duncan multiple range tests at $1 \%$ probability level, it was observed that the highest yield value (17/925 tons per hectare) was related to 90,000 plants per hectare that was lonely arranged in a group, while the lowest yield value (17/245 tons per hectare) was related to 75,000 plants per hectare and was placed in a group with 105,000 plants also (Tables 2 and 3). According to the obtained results from some researches, increasing the number of infertile plants can lead to a decrease of yield after reaching to a maximum density value (Emam and Tadaion, 1999).

\section{1,000 kernel weight}

Effect of different irrigation systems on 1,000 kernel weight was significant at $1 \%$ statistical level (Table 2). An investigation of performed comparisons on 1,000 kernel weight in different irrigation systems showed that furrow system had the highest value of 1,000 kernel weight $(291 / 833 \mathrm{~g})$ which classified in a statistical group with $100 \%$ and $120 \%$ of water requirement and the lowest value of 1,000 kernel weight (179/998 g) belonged to $80 \%$ irrigation level (Table 3). Nesmith and Ritchie (1992) believe that decreasing irrigation volume through a shorter period of grain filling stages can lead to a decrease in 1,000 kernel weight. The effect of crucible density on 1,000 kernel weight was significant (Table 2). It should be noted 
Table 2. An analysis of irrigation variance effect and plant density in one and two row on 'Single Cross Maize (704)' traits

\begin{tabular}{|c|c|c|c|c|c|c|c|c|}
\hline \multirow{2}{*}{$\begin{array}{l}\text { Sources of } \\
\text { variation }\end{array}$} & \multirow[b]{2}{*}{ df } & \multicolumn{7}{|c|}{ Mean-square } \\
\hline & & Harvest index & Ear height & Plant height & $\begin{array}{c}\text { Length of } \\
\text { ear }\end{array}$ & $\begin{array}{l}\text { Number of } \\
\text { kernel in row }\end{array}$ & $\begin{array}{c}\text { 1,000 kernel } \\
\text { weight }\end{array}$ & Yield \\
\hline Replication & 2 & $2.885^{\mathrm{ns}}$ & $58.056 \mathrm{~ns}$ & 1644.6ns & $0.615 \mathrm{~ns}$ & $1.722 \mathrm{~ns}$ & 1983.3ns & $0.255 \mathrm{~ns}$ \\
\hline I & 3 & $12.808^{* *}$ & $250.928^{* *}$ & $1464.8 \mathrm{~ns}$ & $4.951^{* *}$ & $31.315^{* *}$ & $51819.143^{* *}$ & $52.720^{* *}$ \\
\hline Error (a) & 6 & 0.890 & 186.893 & 688.801 & 0.748 & 1.648 & 1191.808 & 1.028 \\
\hline PP & 1 & $3.096^{\mathrm{ns}}$ & $3.059 \mathrm{~ns}$ & $0.759 \mathrm{~ns}$ & $0.204 \mathrm{~ns}$ & $0.056 \mathrm{~ns}$ & $0.065 \mathrm{~ns}$ & $0.354 \mathrm{~ns}$ \\
\hline Error (b) & 2 & 0.314 & 28.361 & 100.990 & 0.104 & 1.722 & 761.616 & 0.472 \\
\hline $\begin{array}{c}\text { Interaction of } \\
\mathrm{I} \times \mathrm{P}\end{array}$ & 3 & $0.314 \mathrm{~ns}$ & $5.327 \mathrm{~ns}$ & $245.967 \mathrm{~ns}$ & $0.113 \mathrm{~ns}$ & $1.241 \mathrm{~ns}$ & $31.784 \mathrm{~ns}$ & $0.034 \mathrm{~ns}$ \\
\hline Error(ab) & 6 & 1.699 & 110.517 & 254.783 & 0.993 & 4.019 & 665.023 & 0.439 \\
\hline D & 2 & $7.963^{*}$ & $843.200^{* *}$ & $2675.978^{* *}$ & $3.122^{* *}$ & $42.722^{* *}$ & $7734.041^{* *}$ & $2.904^{* *}$ \\
\hline $\begin{array}{c}\text { Interaction of } \\
\quad \mathrm{I} \times \mathrm{D}\end{array}$ & 6 & $0.662 \mathrm{~ns}$ & $49.663 \mathrm{~ns}$ & 204.849ns & $0.111 \mathrm{~ns}$ & $0.426 \mathrm{~ns}$ & $1071.091 \mathrm{~ns}$ & $0.050 \mathrm{~ns}$ \\
\hline $\begin{array}{c}\text { Interaction of } \\
P P \times D\end{array}$ & 2 & $2.210 \mathrm{~ns}$ & $4.895 \mathrm{~ns}$ & $64.588 \mathrm{~ns}$ & $0.055 \mathrm{~ns}$ & $1.722 \mathrm{~ns}$ & $234.900 \mathrm{~ns}$ & $0.253 \mathrm{~ns}$ \\
\hline $\begin{array}{l}\text { Interaction of } \\
I \times P P \times D\end{array}$ & 6 & $1.006 \mathrm{~ns}$ & $11.749 \mathrm{~ns}$ & $175.590 \mathrm{~ns}$ & $0.055 \mathrm{~ns}$ & $0.907 \mathrm{~ns}$ & $177.745 \mathrm{~ns}$ & $0.053 \mathrm{~ns}$ \\
\hline Error (d) & 32 & 1.817 & 144.149 & 317.335 & 0.245 & 5.056 & 726.355 & 0.535 \\
\hline \%CV & & 4.31 & 6.31 & 6.51 & 2.63 & 5.74 & 13.5 & 4.3 \\
\hline
\end{tabular}

Table 3. The mean comparisons of irrigation system on 'Single Cross Maize' (704) traits

\begin{tabular}{|c|c|c|c|c|c|}
\hline Irrigation treatments & Harvest index & Ear height $(\mathrm{cm})$ & Number of kernels in row & 1000 kernel weight (g) & Yield ( $\mathrm{t} / \mathrm{ha})$ \\
\hline Water demand $80 \%$ & $30.004 \mathrm{~b}$ & $18.057 \mathrm{~b}$ & $37.222 \mathrm{~b}$ & $179.998 \mathrm{~b}$ & $14.984 \mathrm{~b}$ \\
\hline Water demand 100\% & $31.636 \mathrm{a}$ & $19.043 \mathrm{a}$ & $39.778 \mathrm{a}$ & $286.697 \mathrm{a}$ & $18.210 \mathrm{a}$ \\
\hline Water demand $120 \%$ & $31.739 \mathrm{a}$ & $19.146 \mathrm{a}$ & $40 \mathrm{a}$ & $282.592 \mathrm{a}$ & $18.448 \mathrm{a}$ \\
\hline Furrow irrigation & $31.693 \mathrm{a}$ & $19.119 a$ & $39.778 \mathrm{a}$ & $291.833 \mathrm{a}$ & $18.530 \mathrm{a}$ \\
\hline
\end{tabular}

Table 4. The mean comparisons of different plant density on 'Single Cross Maize 704' traits

\begin{tabular}{ccccccc}
\hline Density & Harvest index & $\begin{array}{c}\text { Ear height } \\
(\mathrm{cm})\end{array}$ & $\begin{array}{c}\text { Plant height } \\
(\mathrm{cm})\end{array}$ & $\begin{array}{c}\text { Length of ear } \\
(\mathrm{cm})\end{array}$ & $\begin{array}{c}\text { Number of } \\
\text { kernels in row }\end{array}$ & $\begin{array}{c}1,000 \text { kernel } \\
\text { weight }(\mathrm{g})\end{array}$ \\
\hline 75,000 plants & $31.221 \mathrm{a}$ & $149.988 \mathrm{~b}$ & $262.153 \mathrm{~b}$ & $19.228 \mathrm{a}$ & $40.500 \mathrm{a}$ & $277.25 \mathrm{a}$ \\
90,000 plants & $31.866 \mathrm{a}$ & $154.095 \mathrm{~b}$ & $275.072 \mathrm{a}$ & $18.781 \mathrm{~b}$ & $39.250 \mathrm{a}$ & $262.09 \mathrm{a}$ \\
105,000 plants & $30.717 \mathrm{~b}$ & $161.672 \mathrm{a}$ & $283.081 \mathrm{a}$ & $18.515 \mathrm{~b}$ & $37.833 \mathrm{~b}$ & $241.49 \mathrm{~b}$ \\
\hline
\end{tabular}

In each column, different letters indicate significant differences at the $5 \%$ level

that with increasing the crucible density, 1,000 kernel weight tended to decrease, while there was not significant differences between 75,000 and 90,000 density levels of crucibles per hectare, respectively (Table 4). The main reasons related to kernel weight in lower density levels result from an increased photosynthetic capability of plants, due to less shading characteristic and increased light absorption (Shakarami, 2009). The results agree with the findings of some researchers (Damavandi and Latifi, 1999; Emam and Tadaion, 1999).

Effect of different irrigation systems on the number of kernel per maize raw was significant at $1 \%$ level (Table 2). An investigation of mean comparisons showed that with increasing the irrigation water volume in different irrigation levels, the number of kernels per raw will also increase. Maximum number of kernel per raw was related to $120 \%$ trickle irrigation and there was not a meaningful statistical difference among furrow system and drip irrigation. Minimum number of kernel resulted from the $80 \%$ irrigation level, which was lonely arranged in a statistical group (Table 3). Westgate experiment results (Westgate, 1995) show that there is a relationship between the decreasing number of kernel per raw and the irrigation level. He states that decreasing the irrigation level, can lead to a decrease of the fertility chance, with a lack of plants forming zygote. Number of kernel per raw through different density levels was significant at $1 \%$ level. It seems that the mentioned part was very sensitive to the environmental conditions and it is strongly affected by competition and environmental factors (Shakarami and Rafiee, 2009). Shakermi and Rafiee (2009), as well as Hashemi Dezfuli and Herbert (1992), reported that the increasing maize plant density would lead to a decrease in the number of kernel per raw due to the late appearance of silk and finally, leading to a lack of correspondence between the pollen production times with the silk appearance.

\section{Earmaize length}

According to an analysis of means comparisons for ear maize length in different irrigation systems, it was observed that moderate value of moisture stress lead to a decrease for the above mentioned trait, whereas the lowest value was observed at $80 \%$ drip irrigation (Tables 2 and 3). Imam and Ranjbar (2000) have generally concluded that extreme moisture stress (with $50 \%$ water requirement) lead to a decrease in ear maize length, but they did not study its effect on various stages of plant growth. Effect of plant density on ear maize length was significant at $1 \%$ statistical level (Tables 2 and 4). Therefore, it can be stated that assimilated material share, distributed into each ear maize, become less 
in high density because of increasing competition between crucibles and resource constraints (Duncan, 1984).

\section{Morphological traits}

The results showed that different irrigation systems had no effect on both crucible height and ear maize height traits from ground (Table 2). The effect of density on crucible height and ear maize was significant at the 1\% level (Table 2). According to a comparison of means for crucible height, it was clear that 105,000 and 75,000 plant densities per hectare, with $283 / 081$ and $262 / 153 \mathrm{~cm}$ averages, included the highest and the lowest plant height values respectively, and it was observed that there is not a significant difference between levels of 90,000 and 105,000 plants per hectare (Table 4). Increasing plant height with density can be due to the competition among plants for light absorption and nutrients. If there is a high density, more competition among plants will be created to absorb the other nutrient sources and environmental factors, whereas with extreme density, the plant height will decrease (Muchow, 1990). It should be noted that 105,000 plant densities per hectare included the highest plant height, which was lonely placed in a group. At the same time, 75,000 crucible densities per hectare included the lowest plant height that was placed in another group with 90,000 densities also (Table 4). Esechie (1992) reported that when density increases from 24 to 74 thousand crucibles per hectare, plant and ear maize height increases too.

\section{Harvest index}

Effect of different irrigation systems on harvest index was significant at $1 \%$ level (Table 2). The highest harvest index was related to $120 \%$ treatment of water requirement $(31 / 739)$ that statistically was not significantly different between furrow system with $100 \%$ water requirement. The lowest harvest index was related to $80 \%$ water requirement with 30/0004 value as harvest index (Table 3). Effect of plant density on harvest index was significant at $5 \%$ level (Table 2). The highest harvest index (31/866) was related to 90,000 plant density per hectare and there was no significant difference between it and 75,000 plant density per hectare, while there was a significant difference between 90,000 plant density per hectare and 105,000 plant per hectare, which included the lowest harvest index (30/717) (Table 4).

The lowest harvest index was obtained from 105,000 plants per hectare. This can be caused by competitions resulted from high density and finally, increasing ear maize infertility percent with pollination disruption. As a final conclusion based on present study, it can be stated that harvest index is under effect of decreasing irritation level at the $1 \%$ probability level.

Denmead and Shaw (1960) stated that water shortage is one of the factors which limit the plant growth. Water shortage can also lead to a decrease of draught material production values, inappropriate distribution of carbohydrates and decreasing the harvest index. Leaf surface index and draught material value will increase in high density; however, kernel ratio, more than material weight, tends to decrease, due to high competition among plants. The results agree with the findings of Shakermi and Rafiee (2009) research. It should be noted that trimming factor through planting process was not significant on all studied traits. The interaction among plant pattern and plant density was not significant on all studied traits.

\section{Conclusions}

Results showed that the highest yield value was related to furrow irrigation, which was arranged in a statistical group with $100 \%$ and $120 \%$ treatment of water requirements. The lowest value for kernel yield was observed in $80 \%$ treatment of water requirements. Furrow system had the highest value of 1,000 kernel weight $(291 / 833 \mathrm{~g})$ which classified in a statistical group with $100 \%$ and $120 \%$ of water requirement. The highest yield value (17/925 tons per hectare) was related to 90,000 plants per hectare that was lonely arranged in a group, while the lowest yield value (17/245 tons per hectare) was related to 75,000 plants per hectare and was placed in a group with 105,000 plants, too. As a result, applying a density of 90,000 plants per hectare can provide better light penetration into plant canopy, which can provide the best performance value for 'Single Cross Maize 704 ' crop based on Miandoab weather condition.

\section{References}

Afshar H, Ashrafi SH, Hasanzadeh V (2007). Application drip irrigation and subsurface irrigation levels in corn varieties in Mashhad. Conference of Agriculture Engineering Research, Karaj, Iran 283-293.

Ahmad AG, Khalili M (2009). Study on yield and water use efficiency of drip tape and furrow irrigation systems in single and two-row planting systems of grain corn. Journal of Irrigation and Drainage Engineering 3(2):71-78.

Baghani J, Alizadeh A (1999). Yield and water use efficiency of drip irrigation and furrow. Journal of Agricultural Engineering Research 5(18):1-10.

Casal JJ, Deregibus VA, Sanchez RA (1985). Variations in tiller dynamics and morphology in Lolium multiflorum Lam., vegetative and reproductive plants as affected by differences in red/far-red irradiation. Annals of Botany 56:533-559.

Cox WJ (1996). Whole-plant physiological and yield response of maize to plant density. Agronomy Journal 88:489-496.

Damavandi A, Latifi N (1999). Effect of row spacing and plant density on yield and yield components of two cultivars of maize. Journal of Agricultural Science and Natural Resources 6(4):25-32.

Dahmardeh M (2011). Effect of plant density and nitrogen rate on PAR absorption and maize yield. American Journal of Plant Physiology 6(1):44-49.

Darusman AH, Stone LR, Spurgeon WE, Lamm FR (1997). Water flux below the root zone vs. irrigation amount in drip-irrigated corn. Agronomy Journal 89:375-379.

Denmead OT, Shaw RH (1960). The effects of soil moisture stress at different stages of growth on the development and yield of corn. Journal of Agriculture 52:272-274.

Duncan WG (1984). A theory to explain the relationship between corn population and grain yield. Journal ofCrop Science 24:1141-1145.

Earley E, Rath B, Sief RD, Hageman RH (2001). Effects of shade applied at different stage of plant development on corn production. Journal of 
548

Crop Science 7:151-159.

Emam Y, Ranjbar H (1999). Effect of low irrigation in vegetation growth time before the appearance of tassel emergence, harvest index and water use efficiency, yield and component yield of maize single cross hybrids. Proceedings of the First National Conference to Discuss Strategies to Deal with the Water Crisis, Zabul, Iran pp 163-173.

Emam Y, Tadion M (1999). Effect of plant density on yield and yield components of corn in Dorodzan river in Fars Province. Journal of Agricultural Science 4:743-750.

Esechie HA (1992). Effect of planting density on growth and yield of irrigated maize (Zea mays L.) in the Batinah Coast Region of Oman. Journal of Agricultural Science 119:165-169.

Faiezbakhash MT, Neamati A, Mokhtarpour H, Mosavat SA, Saberi A, Sheikheh F (2007). Effect of remove tillers and plant density on yield and yield components of sweet corn. Journal of Research and Development 77:125-130.

Glenn F, Daynard T (1973). Effect of genotype, planting pattern and plant density on plant-to-plant variability and grain yield of corn. Journal of Plant Science 54:323-330.

Hashemi-Dezfouli A, Herbert SJ (1992). Intensifying plant density response of corn with artificial shade. Agronomy Journal 84:547-555.

Kohi N, Alizadeh SH, Najafi A (2006). Effect of different levels of drip Irrigation and density on water use efficiency in corn-growing and second-row.Journal of Agricultural Science 1(6):49-58.

Lamm FR, Royers DH, Manges HL (1994). Irrigation scheduling with planned soil water depletion. Transactions of the ASAE 37(5):14911497.

Muchow R, Sinclair T, Ennett J (1990). Temperature and solar radiation effects on potential maize yield across location. Agronomy Journal 82:338-348.
Murphy SD, Takubu Y, Weise SF, Swanton CJ (1996). Effect of planting patterns and inter-row cultivation on competition between corn (Zea mays) and late emerging weeds. Journal of Weed Science 44:865-870.

Nesmith DS, Ritchie JT (1992). Effects of soil water-deficits during tassel emergence on development of maize (Zea mays L.). Field Crops Research 28:251-256.

Samian M, Naderi Mahdei K, Saadi H, Movahedi R (2015). Identifying factors affecting optimal management of agricultural water. Journal of the Saudi Society of Agricultural Sciences 14(1):11-18.

Seidehvand M (1999). Effects of different densities and planting patterns on growth and physiological indices of forage maize. MSc Thesis in Agronomy, University of Sistan and Balochestan, Iran.

Shakarami G, Rafiee M (2009). Response of corn (Zea mays L.) to planting pattern and density in Iran. American-Eurasian Journal of Agricultural and Environmental Sciences 5(1):69-73.

Turgut I (2000). Effects of plant populations and nitrogen doses on fresh ear yield and yield components of sweet corn (Zea mays Saccharata Sturt) grown under bursa conditions. Turkish Journal of Agriculture and Forestry 24:341-347.

Westgate ME (1994). Seed formation in maize during drought. In: Boote K,J, Bennett JM, Scinclair TR, Paulsen GM (Eds). Physiology and determination of crop yield. CSSA-ASA-SSSA, Madison, WI pp 361365.

Widdicombe WD, Thelen KD (2002). Row width and plant density effect on corn grain production in the northern Corn Belt. Agronomy Journal 94:1020-1023. 